DOI: $10.15193 / \mathrm{zntj} / 2019 / 119 / 284$

\author{
ADAM ZWOLAN, MAŁGORZATA KUDLIK, LECH ADAMCZAK, \\ DOROTA PIETRZAK
}

\title{
WPLYW DODATKU CZARNUSZKI (NIGELLA SATIVA) NA WYBRANE WYRÓŻNIKI JAKOŚCI KULEK Z MIĘSA DROBIOWEGO
}

\author{
Streszczenie
}

Celem pracy było określenie wpływu dodatku czarnuszki siewnej (Nigella sativa) na wybrane wyróżniki jakości kulek z mięsa drobiowego podczas dwóch tygodni ich przechowywania w warunkach chłodniczych. Wytworzono trzy warianty kulek różniących się wielkością dodatku czarnuszki: $\mathrm{K}$ - próba kontrolna bez dodatku czarnuszki, C-0,2 - dodatek 0,2 \% czarnuszki, C-0,3 - dodatek 0,3\% czarnuszki. W gotowych wyrobach oznaczono: skład chemiczny, wielkość wycieku przechowalniczego oraz wydajność obróbki cieplnej. Zmierzono także parametry barwy w skali CIE L*a*b*, wskaźnik TBARS, aktywność wody oraz siłę cięcia. Przeprowadzono również ocenę sensoryczną kulek mięsnych, w której uwzględniono następujące wyróżniki: barwę, zapach, smak, twardość oraz ogólną pożądalność. Badania przeprowadzono po $24 \mathrm{~h}$ od wytworzenia wyrobów oraz po 1 i 2 tygodniach ich chłodniczego przechowywania. Zastosowanie dodatku czarnuszki istotnie spowolniło procesy utleniania tłuszczów zachodzące w zapakowanych próżniowo kulkach z mięsa drobiowego w trakcie dwóch tygodni przechowywania w warunkach chłodniczych. Po 24 h od wytworzenia średnie wartości wskaźnika TBARS w pieczonych kulkach wynosiły $0,50 \div 0,62 \mathrm{mg} \mathrm{AM} / \mathrm{kg}$ produktu. Po tygodniu przechowywania stwierdzono istotne przyspieszenie procesów utleniania lipidów we wszystkich wariantach wytworzonych kulek, przy czym niższymi wartościami wskaźnika TBARS charakteryzowały się warianty z dodatkiem czarnuszki. Dodatek czarnuszki spowodował pociemnienie barwy wyrobów (niższe wartości parametrów barwy $\mathrm{L}^{*} \mathrm{i} \mathrm{b}^{*}$ ) oraz wzrost siły cięcia w porównaniu z próbą kontrolną. Według oceniających najwyższą pożądalnością charakteryzowały się kulki mięsne z 0,3-procentowym dodatkiem czarnuszki. Wyniki przeprowadzonej oceny sensorycznej wskazują, że dodatek czarnuszki może być stosowany do produkcji wyrobów należących do grupy żywności wygodnej, które będą atrakcyjne dla konsumentów.

Słowa kluczowe: czarnuszka, mięso drobiowe, kulki mięsne, jakość, utlenianie tłuszczów

\section{Wprowadzenie}

Sektor żywności wygodnej jest jednym z najdynamiczniej rozwijających się działów branży spożywczej w Polsce. Dotyczy to zwłaszcza produktów z mięsa drobiowe-

Mgr inż. A. Zwolan, mgr inż. M. Kudlik, dr inż. L. Adamczak, dr hab. inż. D. Pietrzak, Katedra Technologii Żywności, Wydz. Nauk o Żywności, Szkoła Główna Gospodarstwa Wiejskiego w Warszawie, ul.Nowoursynowska159 C,02-776Warszawa.Kontakt:adam_zwolan@sggw.pl 
go, które są chętnie kupowane przez konsumentów z uwagi na dużą wartość odżywczą surowca, a jednocześnie niską cenę. Mięso drobiowe jest źródłem pełnowartościowego białka i zawiera mało tłuszczu, przy czym skład kwasów tłuszczowych jest korzystny dla zdrowia człowieka. Ze względu na dużą zawartość nienasyconych kwasów tłuszczowych produkty drobiowe są jednak podatne na procesy utleniania, które mogą zachodzić zarówno podczas ich wytwarzania, jak i przechowywania $[5,16,23]$.

W wyniku utleniania lipidów mięsa powstaje wiele związków, m.in. niskocząsteczkowe substancje lotne, w tym krótkołańcuchowe aldehydy oraz kwasy, które są wtórnymi produktami utleniania. Przyczyniają się one do obniżenia jakości produktów mięsnych poprzez zmianę barwy, smaku i zapachu, ale również wykazują negatywny wpływ na ich wartość odżywczą i bezpieczeństwo żywnościowe [4, 7, 12, 20, 31]. W celu ograniczenia tych niekorzystnych zmian w przemyśle mięsnym stosuje się dodatek przeciwutleniaczy, najczęściej syntetycznych, takich jak: kwas askorbinowy E 300 i kwas erytrobowy (izoaskorbinowy) - E 315 oraz ich sole sodowe (odpowiednio E 301 i E 316), galusany - E 310, E 311, E 312, TBHQ (trzeciorzędowy butylohydroksychinon) - E 319, BHA (mono-tert-butylohydroksyanizol) - E 320. Do wybranych produktów może być dodawany również ekstrakt z rozmarynu - E 392 [29]. Prowadzone są jednocześnie badania w kierunku wykorzystania nowych źródeł związków o właściwościach przeciwutleniających, szczególnie polifenolowych, występujących w wielu roślinach, w tym ziołach i przyprawach, m.in. czarnuszce siewnej, ale także w pestkach oraz w ekstraktach, m.in. z nasion zbóż, ziół, pestek i skórek owoców oraz herbat [10, 13, 17, 22, 24, 35].

Nasiona czarnuszki siewnej charakteryzuje duża wartość odżywcza. Zawierają one $36 \div 38 \%$ thuszczu, $25 \div 32 \%$ węglowodanów, $22 \div 26 \%$ białka, występują w nich także karotenoidy, tokoferole, witaminy z grupy B oraz wiele składników mineralnych. Olej z nasion czarnuszki bogaty jest w nienasycone kwasy thuszczowe, w tym rzadko występujący w przyrodzie kwas eikozadienowy, fosfolipidy o dużej zawartości fosfatydylocholiny oraz fitosterole $[1,28]$. Zawiera on w swoim składzie olejek eteryczny w ilości $0,4 \div 2,5 \%$, w którym znajdują się m.in. trans-anetol, limonen, p-cymen, a także tymochinon, tymohydrochinon oraz ditymochinon. Tymochinon wykazuje silne właściwości przeciwutleniające, hamuje cyklooksygenazę i 5-lipooksygenazę w szlaku kwasu arachidonowego [6, 21, 30].

Czarnuszka siewna jest obecnie stosowana w różnych gałęziach przemysłu spożywczego, m.in. jako dodatek do pieczywa i ciast, marynat oraz serów [6]. Ze względu na właściwości przeciwutleniające mogłaby być również stosowana do produkcji przetworów z mięsa drobiowego.

Celem pracy było określenie wpływu dodatku czarnuszki siewnej na wybrane wyróżniki jakości kulek z mięsa drobiowego podczas dwóch tygodni ich przechowywania w warunkach chłodniczych. 


\section{Material i metody badań}

Materiał doświadczalny stanowiły kulki mięsne, których skład surowcowy przedstawiono w tab. 1. Badania wykonano w trzech powtórzeniach. Każdorazowo wytwarzano trzy warianty kulek mięsnych różniących się wielkością dodatku czarnuszki siewnej: $\mathrm{K}$ - bez dodatku czarnuszki, C-0,2 - z dodatkiem 0,2 \% czarnuszki, C-0,3 $\mathrm{z}$ dodatkiem $0,3 \%$ czarnuszki.

Tabela 1. Skład surowcowy kulek z mięsa drobiowego [\%]

Table 1. Chemical composition of poultry meatballs [\%]

\begin{tabular}{|c|c|c|c|}
\hline \multirow[t]{2}{*}{ Składnik / Ingredient } & \multicolumn{3}{|c|}{$\begin{array}{l}\text { Wariant produktu } \\
\text { Variant of product }\end{array}$} \\
\hline & $\mathrm{K}$ & $\mathrm{C}-0,2$ & $\mathrm{C}-0,3$ \\
\hline Mięso z nóg kurcząt / Poultry leg meat & \multicolumn{3}{|c|}{75,0} \\
\hline Podgardle skórowane / De-skinned yowl & \multicolumn{3}{|c|}{10,0} \\
\hline Masa jajowa / Whole egg pulp & \multicolumn{3}{|c|}{5,0} \\
\hline Uwodniona bułka pszenna (1:1) / Hydrated wheat bun (1:1) & \multicolumn{3}{|c|}{10,0} \\
\hline Surowce podstawowe razem / Basic raw materials in total & \multicolumn{3}{|c|}{100} \\
\hline Pieprz / Pepper* & \multicolumn{3}{|c|}{0,1} \\
\hline Czarnuszka siewna / Black cumin* & - & 0,2 & 0,3 \\
\hline
\end{tabular}

Objaśnienie / Explanatory note:

* - w stosunku do masy surowców podstawowych / in relation to whole load of basic raw materials

Surowiec mięsny do badań zakupiono w zakładzie „SuperDrob” S.A. (Karczew). Czarnuszkę zakupiono w firmie „Agnex” (Białystok) - kraj pochodzenia produktu: Indie/Syria w zależności od dostępnej partii. Mięso z nóg kurcząt i podgardle rozdrabniano w wilku laboratoryjnym z siatką o średnicy otworów 4,5 mm. Wszystkie składniki odważano z dokładnością do $0,1 \mathrm{~g}$, wprowadzano do mieszarki laboratoryjnej Kenwood MDJ85 z mieszadłem typu K (De’Longhi, Włochy) i mieszano przez 5 min do równomiernego rozprowadzenia składników. Z wytworzonych farszów formowano kulki o masie ok. $40 \mathrm{~g}( \pm 1 \mathrm{~g})$, podmrażano je w mroźni w temp. $-18{ }^{\circ} \mathrm{C}$ przez $1 \mathrm{~h}$ w celu utrwalenia kształtu, a następnie pakowano w torebki polietylenowe próżniowo pod zmniejszonym do $100 \mathrm{mBar}$ ciśnieniem, przy użyciu pakowarki firmy MULTIVAC® (Multivac, Polska). Do czasu przeprowadzenia badań kulki przechowywano w mroźni (maksymalnie 2 tygodnie). Przed wykonaniem serii badań kulki mięsne wyjmowano z mroźni i poddawano je obróbce cieplnej w piecu konwekcyjnoparowym (w temp. $180{ }^{\circ} \mathrm{C}$ do uzyskania w centrum geometrycznym $80{ }^{\circ} \mathrm{C}$, bez nawilżania). Po wystudzeniu kulki pakowano próżniowo i przechowywano $\mathrm{w}$ warunkach chłodniczych (w temp. $4-6^{\circ} \mathrm{C}$ ). Po określonym czasie przechowywania, trwającym 24 h, 1 tydzień oraz 2 tygodnie, w kulkach oznaczano ilość wycieku przechowalnicze- 
go, podstawowy skład chemiczny metodą spektrometrii transmisyjnej w bliskiej podczerwieni (NIT) z wykorzystaniem kalibracji w sztucznych sieciach neuronowych (ANN) [27] FoodScan (Foss Analytical, Dania) oraz zawartość aldehydu malonowego (AM) wyrażoną w $\mathrm{mg} / \mathrm{kg}$ produktu (wskaźnik TBARS) [32]. Przeprowadzano także pomiar parametrów barwy $\mathrm{w}$ systemie CIE L*a*b* przy użyciu kolorymetru MINOLTA ${ }^{\circledR}$ CR-200 (Konica Minolta, Japonia). Bezwzględną różnicę barwy (pomiędzy poszczególnymi wariantami w zależności od czasu przechowywania) obliczano $\mathrm{z}$ równania [3]:

$$
\Delta \mathrm{E}=\sqrt{(\Delta \mathrm{L})^{2}+(\Delta \mathrm{a})^{2}+(\Delta \mathrm{b})^{2}}
$$

gdzie:

$\Delta \mathrm{E}$ - bezwzględna różnica barw,

$\Delta \mathrm{L}, \Delta \mathrm{a}, \Delta \mathrm{b}$ - różnice parametrów barwy kulek mięsnych.

Wykonywano również pomiary: aktywności wody przy użyciu aparatu AQUA LAB $^{\circledR}$ (Decagon Devices) oraz siły cięcia przy zastosowaniu aparatu ZWICKI $1120^{\circledR}$ (Zwick GmbH \& Co., Ulm, Niemcy). Kulki mięsne poddano także ocenie sensorycznej. Do oceny zastosowano niestrukturowaną skalę graficzną długości $10 \mathrm{~cm}(0-$ 10 j.u.) z oznaczeniami na obu jej biegunach. Uwzględniono następujące wyróżniki: barwę powierzchni (zbyt jasna - zbyt ciemna), twardość (zbyt miękkie - zbyt twarde), zapach i smak mięsny oraz przyprawowy (niepożądany - bardzo pożądany), a także ogólną pożądalność. W przypadku oceny ogólnej pożądalności oznaczenia brzegowe opisano określeniami: „bardzo niepożądany - bardzo pożądany”. Oceny dokonywała grupa 15 osób przeszkolonych w zakresie jej przeprowadzania. Badanie przeprowadzono w warunkach zbliżonych do domowych.

Uzyskane wyniki poddano analizie statystycznej z zastosowaniem jednoczynnikowej analizy wariancji. Istotność różnic między wartościami średnimi weryfikowano testem Tukeya HSD przy $\mathrm{p} \leq 0,05$.

\section{Wyniki i dyskusja}

Ubytki masy podczas obróbki cieplnej kulek mięsnych wynosiły średnio 13,6 $14,4 \%$ i były typowe dla tego typu produktów. Skład chemiczny kulek był zbliżony bez względu na zastosowany dodatek czarnuszki. Kulki zawierały średnio 13,6 $14,4 \%$ tłuszczu, $62,0 \div 64,0 \%$ wody oraz $19,2 \div 19,5 \%$ białka. Skład chemiczny produktów mięsnych zależy w głównej mierze od składu recepturowego oraz zastosowanej obróbki cieplnej mającej wpływ na wielkość ubytków masy [33]. W mięsie udowym kurcząt bez skóry zawartość wody stanowi ok. $74 \div 75 \%$, białka $-17 \div 19 \%$ oraz tłuszczu $-5 \div 6 \%$ [18]. Większa zawartość tłuszczu w wyprodukowanych kulkach wynikała z zastosowanego dodatku podgardla. Tłuszcz w produktach mięsnych, 
szczególnie drobno rozdrobnionych, jest bardzo ważnym składnikiem, ponieważ kształtuje ich teksturę oraz nadaje smakowitość i soczystość [11].

Podczas przechowywania $\mathrm{w}$ warunkach chłodniczych w zapakowanych próżniowo produktach mięsnych może pojawiać się wyciek. W przypadku kulek mięsnych ilość wycieku w opakowaniu kształtowała się na zbliżonym poziomie i wynosiła średnio $0,6 \div 0,8 \%$ (tab. 2). Zgodnie z wynikami badań Pietrzak i Myron [26] ilość wycie$\mathrm{ku} \mathrm{w}$ zapakowanych próżniowo hamburgerach z mięsa drobiowego z dodatkiem ekstraktu z rozmarynu była 3 - 4 razy większa niż w niniejszej pracy.

Kulki mięsne $\mathrm{z}$ dodatkiem czarnuszki charakteryzowała ciemniejsza barwa w porównaniu z wyrobem kontrolnym, o czym świadczą niższe wartości parametrów barwy $L^{*}$ i b*. W przypadku kulek $\mathrm{z}$ większym dodatkiem czarnuszki były to różnice statystycznie istotne $(\mathrm{p} \leq 0,05)$. Taka tendencja utrzymała się podczas dwóch tygodni przechowywania zapakowanych próżniowo wyrobów w warunkach chłodniczych, przy czym stwierdzono, że wartości parametru barwy L* kulek mięsnych stopniowo zwiększały się, a wartości parametrów barwy a* i b* - zmniejszały się (tab. 2). Na podstawie obliczeń $\Delta \mathrm{E}$ (tab. 3) wykazano, że różnice barwy próbek z większym dodatkiem czarnuszki $\mathrm{w}$ stosunku do pozostałych wyrobów mogły być zauważalne wzrokowo $(\Delta \mathrm{E}>3,5)$.

Barwa jest bardzo ważnym wyróżnikiem jakości, decydującym o chęci zakupu produktów mięsnych. Jest ona jako pierwsza poddawana ocenie przez konsumentów, którzy na jej podstawie często oceniają jakość produktów [23]. Barwa kulek mięsnych z dodatkiem czarnuszki była istotnie ciemniejsza z powodu ciemnego zabarwienia użytego dodatku.

Wpływ dodatku naturalnych ekstraktów z rozmarynu oraz czosnku jako substancji o charakterze przeciwutleniającym na barwę kulek z mięsa wołowego został wykazany także przez Fernández-López i wsp. [10], którzy zauważyli, że wraz ze wzrostem wielkości dodatku barwa produktów ulegała rozjaśnieniu. Autorzy tłumaczyli to obecnością związków o charakterze przeciwutleniającym, które opóźniają tworzenie się metmioglobiny odpowiadającej za ciemniejszą barwę wyrobów mięsnych. Pietrzak i Myron [26] nie odnotowały wpływu ekstraktu na ogólną jasność produktu (L*) po zastosowaniu dodatku rozmarynu do hamburgerów drobiowych.

W kulkach mięsnych z dodatkiem czarnuszki wartości siły cięcia były wyższe $\mathrm{w}$ porównaniu $\mathrm{z}$ wyrobem kontrolnym, ale różnice statystycznie istotne $(\mathrm{p} \leq 0,05)$ stwierdzono tylko po $24 \mathrm{~h}$ od wytworzenia oraz po 2 tygodniach przechowywania w warunkach chłodniczych (tab. 2).

Zastosowanie dodatku czarnuszki ograniczyło niekorzystne zmiany lipidów w kulkach z mięsa drobiowego. Po 24 h od wytworzenia wartości wskaźnika TBARS $\mathrm{w}$ próbkach $\mathrm{z}$ dodatkiem czarnuszki były istotnie niższe $(\mathrm{p} \leq 0,05)$ niż $\mathrm{w}$ wyrobie 


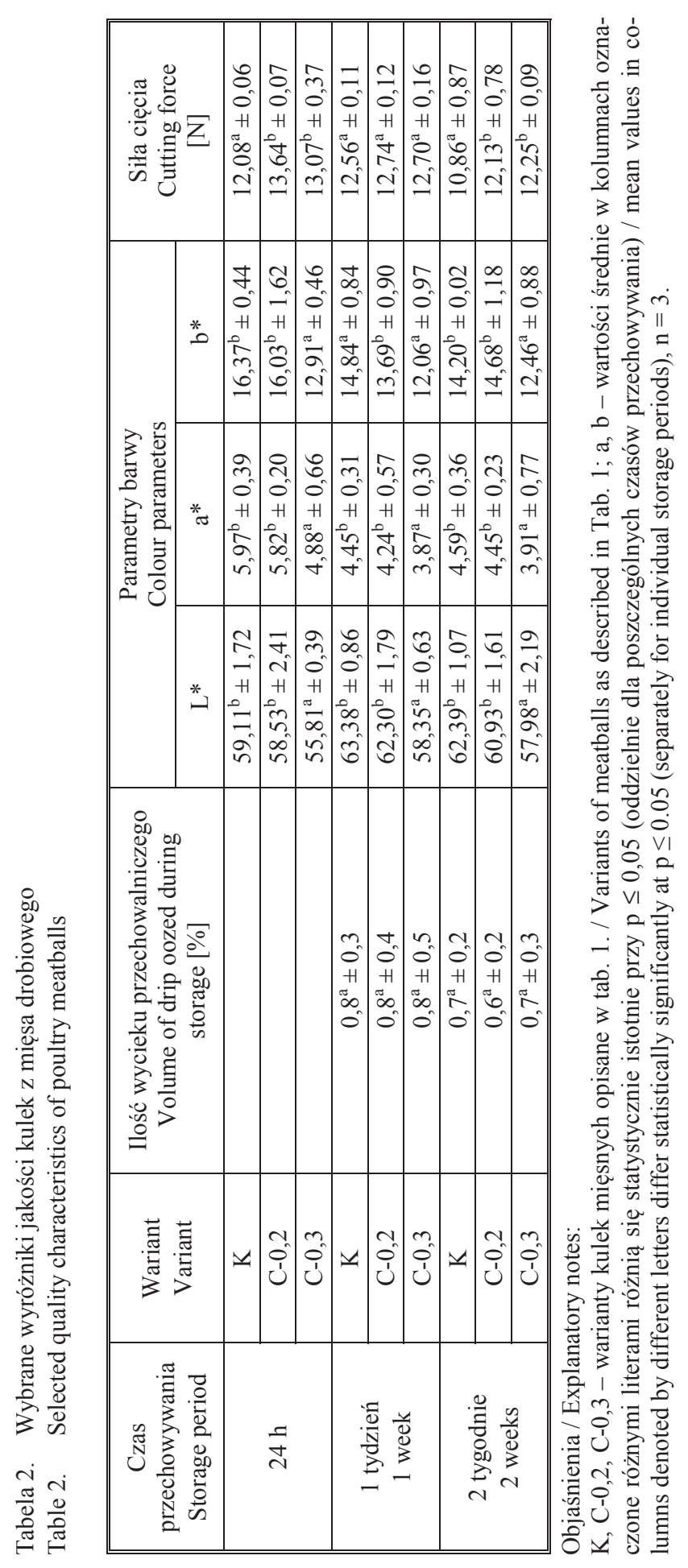


Tabela 3. Bezwzględne różnice barw $\Delta \mathrm{E}$

Table 3. Absolute colour space $\Delta \mathrm{E}$

\begin{tabular}{|c|c|c|}
\hline \multirow{2}{*}{$\begin{array}{c}\text { Czas przechowywania } \\
\text { Storage period }\end{array}$} & $\begin{array}{c}\text { Wariant } \\
\text { Variant }\end{array}$ & $\Delta \mathrm{E}$ \\
\hline \multirow{3}{*}{$24 \mathrm{~h}$} & $\mathrm{~K}-\mathrm{C}-0,2$ & 0,7 \\
\cline { 2 - 3 } & $\mathrm{K}-\mathrm{C}-0,3$ & 4,9 \\
\cline { 2 - 3 } & $\mathrm{C}-0,2-\mathrm{C}-0,3$ & 4,2 \\
\hline \multirow{2}{*}{$\begin{array}{c}1 \text { tydzień } \\
1 \text { week }\end{array}$} & $\mathrm{K}-\mathrm{C}-0,2$ & 1,6 \\
\cline { 2 - 3 } & $\mathrm{K}-\mathrm{C}-0,3$ & 5,8 \\
\cline { 2 - 3 } 2 & $\mathrm{C}-0,2-\mathrm{C}-0,3$ & 4,3 \\
\hline \multirow{2}{*}{$\begin{array}{c}2 \text { tygodnie } \\
2 \text { weeks }\end{array}$} & $\mathrm{K}-\mathrm{C}-0,2$ & 1,5 \\
\cline { 2 - 3 } & $\mathrm{K}-\mathrm{C}-0,3$ & 4,8 \\
\hline
\end{tabular}

Objaśnienie / Explanatory note:

Warianty kulek mięsnych opisane w tab. 1. / Variants of meatballs as described in Tab. 1

kontrolnym (rys. 1). Taka tendencja utrzymała się podczas dwóch tygodni przechowywania w warunkach chłodniczych kulek zapakowanych próżniowo. Wykazano również, że w wyrobach $\mathrm{z}$ większym dodatkiem czarnuszki utlenianie lipidów zachodziło istotnie wolniej niż w próbkach z 0,2-procentowym jej dodatkiem.

Przeprowadzono wiele badań w kierunku zastosowania w produktach mięsnych naturalnych substancji o charakterze przeciwutleniającym, takich jak: wawrzyn i szałwia [2], gałka muszkatołowa oraz skórki owoców cytrusowych [22], ekstrakt z rozmarynu [10]. Wykazano, że dodatek ekstraktu z rozmarynu znacząco spowalniał proces utleniania tłuszczów w zapakowanych próżniowo hamburgerach z mięsa kurcząt [26] oraz w kulkach z mięsa indyczego [14]. Ekstrakt z rozmarynu był pierwszym naturalnym dodatkiem, który w oficjalnym biuletynie Komisji Europejskiej został uznany za bezpieczny i skuteczny przeciwutleniacz nadający się do konserwowania żywności [9]. Według Hęś i wsp. [12] dodatek ekstraktów z tymianku, zielonej herbaty oraz rozmarynu spowodował ograniczenie zmian oksydacyjnych w suszonym mięsie przechowywanym przez 24 tygodnie w temp. $18-20^{\circ} \mathrm{C}$, bez dostępu światła. Ekstrakty z herbaty i tymianku charakteryzowała jednak wyższa aktywność przeciwutleniająca w porównaniu z ekstraktem z rozmarynu. Wyniki uzyskane w badaniach własnych są zbieżne z wynikami Lu i wsp. [19], którzy wykazali, że dodatek przypraw, takich jak czarny pieprz oraz imbir przyczynił się do istotnego obniżenia (o ok. $25 \%$ ) wartości wskaźnika TBARS w kulkach z mięsa drobiowego w porównaniu z wyrobem kontrolnym. Van Hecke i wsp. [34] stwierdzili, że dodatek pieprzu cayenne i kminku ograniczył proces utleniania lipidów podczas ogrzewania produktów mięsnych. 


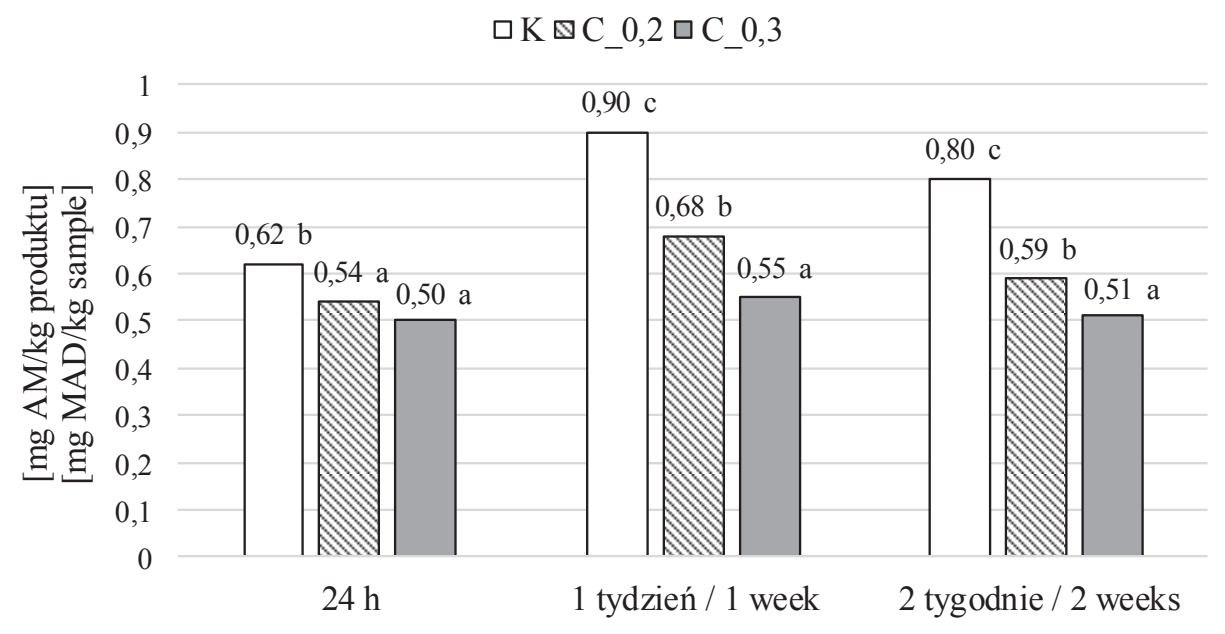

Czas przechowywania / Storage period

Objaśnienia / Explanatory notes:

$\mathrm{K}, \mathrm{C}-0,2, \mathrm{C}-0,3$ - warianty kulek mięsnych opisane w tab. 1. / variants of meatballs as described in Tab. 1. $\mathrm{Na}$ rysunku przedstawiono wartości średnie w postaci słupków / Figure shows mean values (bars); $\mathrm{n}=3$; a, b, c - wartości średnie oznaczone różnymi literami różną się statystycznie istotnie ( $\mathrm{p} \leq 0,05)$ - oddzielnie dla poszczególnych czasów przechowywania / mean values denoted by different letters differ statistically significantly $(\mathrm{p} \leq 0.05)$ - separately for individual storage periods.

Rys. 1. Wartości wskaźnika TBARS w kulkach z mięsa drobiowego

Fig. 1. TBARS indicator value in poultry meatballs

Po przeanalizowaniu wyników oceny sensorycznej kulek mięsnych (tab. 4), można stwierdzić, że dodatek czarnuszki siewnej wpłynął w korzystny sposób na ich ogólną pożądalność. Po 2 tygodniach przechowywania stwierdzono podobną tendencję. Można jednak zauważyć tendencję do obniżenia not za ogólną pożądalność wraz $\mathrm{z}$ upływem czasu.

Kulki mięsne z dodatkiem czarnuszki oceniono wyżej za takie wyróżniki, jak: twardość, zapach i smak mięsny oraz przyprawowy. Wykazano, że kulki mięsne charakteryzujące się bardziej intensywnym smakiem mięsnym, oceniono niżej za smak przyprawowy. Dla konsumentów tego typu produktów bardziej istotny jest smak przyprawowy, o czym świadczy wyższa ocena za ogólną pożądalność tych produktów. W ocenie sensorycznej twardości wariant kontrolny zarówno po 1 , jak i po 2 tygodniach przechowywania oceniony został jako najbardziej optymalny. Charakteryzował się on również istotnie niższą siłą cięcia. Peters i wsp. [25] wykazali, że dodatek czosnku, bazylii i oregano do produktów mięsnych typu pieczeń o zmniejszonej zawartości tłuszczu wpłynął korzystnie na ocenę ich ogólnej pożądalności przez 


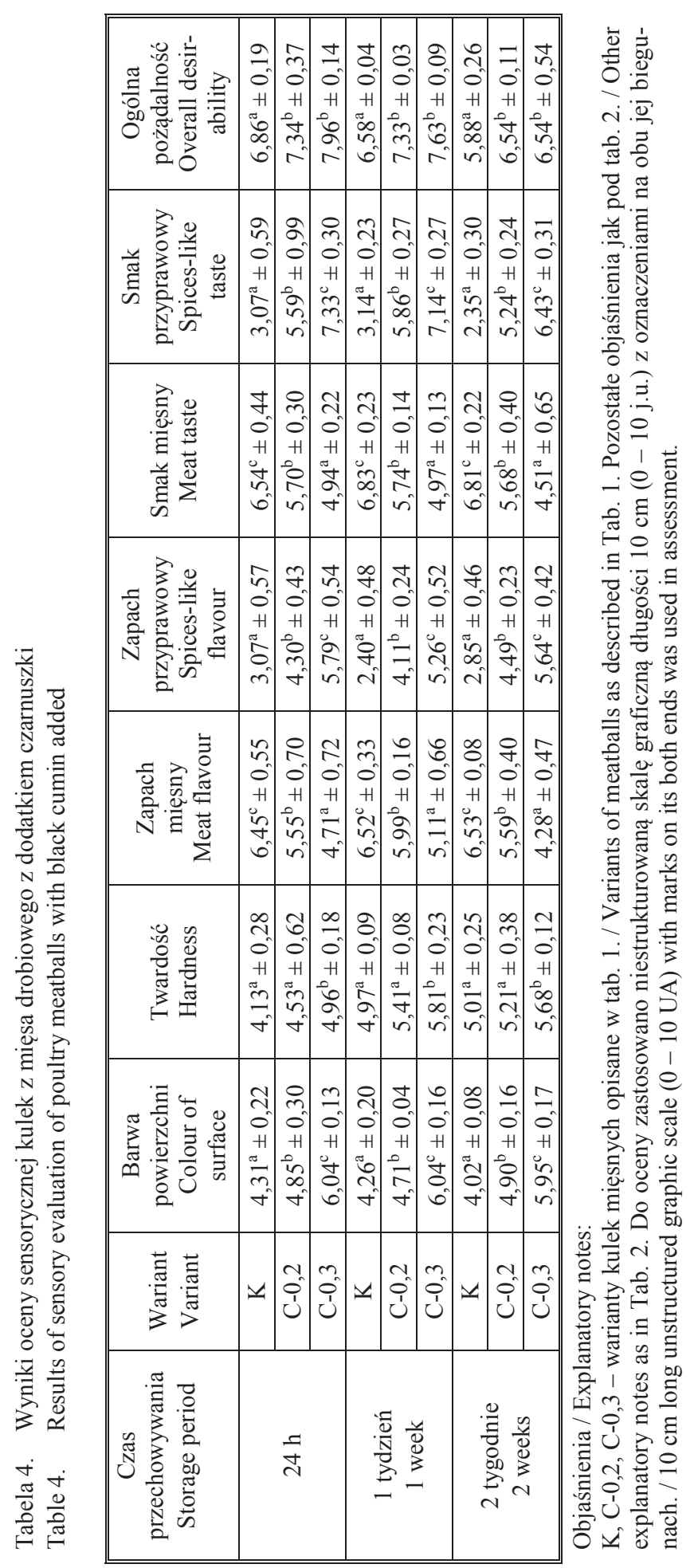


oceniających. Ding i wsp. [8] zaobserwowali, że dodatek mąki z kwiatów liczi do klopsów z mięsa wieprzowego spowodował wzrost twardości produktu po 2 tygodniach przechowywania. Zmiana ta nie została jednak negatywnie odebrana przez zespół oceniający. Karpińska i wsp. [15], po przeprowadzeniu oceny sensorycznej kulek mięsnych wyprodukowanych z dodatkiem mieszanki przypraw (m.in. szałwii, czosnku i majeranku) o właściwościach przeciwutleniających oraz przechowywanych przez 2 i 4 dni, wykazali, że produkty te charakteryzowały się wyższymi notami pod względem wyróżników, takich jak smak i zapach w porównaniu z wariantem kontrolnym.

\section{Wnioski}

1. Zastosowanie dodatku czarnuszki istotnie spowolniło wzrost wskaźnika TBARS w zapakowanych próżniowo kulkach z mięsa drobiowego podczas 2 tygodni przechowywania w warunkach chłodniczych.

2. Kulki mięsne $\mathrm{z}$ dodatkiem czarnuszki charakteryzowała ciemniejsza barwa (o czym świadczą niższe wartości parametrów barwy $L^{*}$ i b*) oraz wyższa siła cięcia w porównaniu z wyrobem kontrolnym.

3. Wyniki oceny sensorycznej wskazują, że dodatek czarnuszki może być stosowany do wytwarzania produktów należących do grupy żywności wygodnej, które będą atrakcyjne dla konsumentów.

\section{Literatura}

[1] Abdalla M.: Czarnuszka jako surowiec piekarski. Przegl. Piek. Cuk., 2002, 50 (3), 6-8.

[2] Akcan T., Estevez M., Serdaroglu M.: Antioxidant protection of cooked meatballs during frozen storage by whey protein edible films with phytochemicals from Laurus nobilis L. and Salvia officinalis. LWT - Food Sci. Technol., 2017, 77, 323-331.

[3] Anonim: Barwa i jakość. Heidelberg Druckmaschinen AG, Kurfursten-Anlage 1999, pp. 52-60.

[4] Antolovich M., Prenzler P.D., Patsalides E., McDonald S., Robards K.: Methods of testing antioxidant activity. The Analyst, 2002, 127 (1), 183-198.

[5] Augustyńska-Prejsnar A., Ormian M., Gajdek G.: Preferencje nabywcze "żywności wygodnej” pochodzenia drobiowego w opinii młodzieży akademickiej. J. Agrib. Rural Devel., 2014, 4 (34), 1726.

[6] Borusiewicz M., Janeczko Z.: Nigella sativa L. - roślinny surowiec o właściwościach plejotropowych. Prace Przeglądowe UJ, 2015, 4 (16), 223-236.

[7] Campo M.M., Nute G.R., Hughes S.I., Enser M., Wood J.D., Richardson R.I.: Flavour perception of oxidation in beef. Meat Sci., 2006, 72, 303-311.

[8] Ding Y., Wang S.-Y., Yang D.-J., Chang M.-H., Chen Y.-C.: Alleviative effects of litchi (Litchi chinesis Sonn.) flower on lipid peroxidation and protein degradation in emulsified pork meatballs. J. Food Drug Anal., 2015, 23, 501-508.

[9] Dyrektywa Komisji 2010/67/UE z dnia 20 października 2010 r. zmieniająca dyrektywę 2008/84/WE ustanawiającą szczególne kryteria czystości dla dodatków do środków spożywczych innych niż barwniki i substancje słodzące. Dz. U. L 277, ss. 17-26, z 21.10.2010. 
[10] Fernandez-López J., Zhi N., Aleson-Carbonell L., Perez-Alvarez J.A., Kuri V.: Antioxidant and antibacterial activities of natural extracts: Application in beef meatballs. Meat Sci., 2005, 69, 371380.

[11] Florowski T., Adamczak L., Fuertes Hernandez O., Moreno Franco M.B., Tyburcy A.: Ocena wpływu stopnia substytucji tłuszczu inuliną na jakość pieczonych pasztetów drobiowych. Rocz. Inst. Przem. Mięs. Tłusz., 2008, 46 (2), 119-126.

[12] Hęś M., Jeżewska M., Szymandera-Buszka K., Gramza-Michałowska A.: Wpływ dodatków przeciwutleniających na wybrane wskaźniki wartości odżywczej mięsa suszonego. Żywność. Nauka. Technologia. Jakość, 2011, 5 (78), 94-106.

[13] Jiang J., Xiong Y.L.: Natural antioxidants as food and feed additives to promote health benefits and quality of meat products: A review. Meat Sci., 2016, 120, 107-117.

[14] Karpińska-Tymoszczyk M.: Effect of the addition of ground rosemary on the quality and shelf-life of turkey meatballs during refrigerate storage. Brit. Poultry Sci., 2008, 49, 742-750.

[15] Karpińska M., Borowski J., Donowska-Oziewicz M.: The use of natural antioxidants in ready-toserve-food. Food Chem., 2001, 72 (1), 5-9.

[16] Karpińska-Tymoszczyk M., Danowska-Oziewicz M., Draszanowska A., Antoniak L: Wpływ syntetycznego i naturalnego przeciwutleniacza oraz obróbki cieplnej na jakość wyrobów z mięsa indyczego. Brom. Chem. Toksykol., 2014, 47 (3), 469-474.

[17] Karre L., Lopez K., Getty K.J.K.: Natural antioxidants in meat and poultry products. Meat Sci., 2013, 94, 220-227.

[18] Kiczorowska B., Samolińska W., Al-Yasiry A.R.M., Winiarska-Mieczan A., Kwiecień M.: Wartość odżywcza mięsa drobiowego pochodzącego z produkcji konwencjonalnej i ekologicznej. Probl. Hig. Epidemiol., 2015, 96 (3), 598-602.

[19] Lu F., Kuhnle G.K., Cheng Q.: The effect of common spices and meat type on the formation of heterocyclic amines and polycyclic aromatic hydrocarbons in deep-fried meatballs. Food Control, 2018, 92, 399-411.

[20] Łopacka J., Lipińska A.: Zmiany oksydacyjne zachodzące w czasie przechowywania mięsa wołowego w modyfikowanej atmosferze gazów oraz obróbki termicznej i ich potencjalne skutki zdrowotne. Probl. Hig. Epidemiol., 2015, 96 (4), 719-726.

[21] Mańkowska D., Bylka W.: Nigella sativa L. - związki czynne, aktywność biologiczna. Herba Polonica, 2009, 55 (1), 109-125.

[22] Nishad J., Koley T.K., Varghese E., Kaur C.: Synergistic effects of nutmeg and citrus peel extracts in imparting oxidative stability in meat bals. Food Reas. Int., 2018, 106, 1026-1036.

[23] Orkusz A.: Czynniki kształtujące jakość mięsa drobiu grzebiącego. Praca przeglądowa. Nauki Inż. Technol., 2015, 1 (16), 47-60.

[24] Oswell N.J., Thippareddi H., Pegg R.B.: Practical use of natural antioxidants in meat products in the U.S.: A review. Meat Sci., 2018, 145, 469-479.

[25] Peters J.C., Polsky S., Stark R., Zhaoxing P., Hill J.O.: The influence of herbs and spices on overall liking of reduced fat food. Appetite, 2014, 79, 183-188.

[26] Pietrzak D., Myron M.: Wpływ dodatku ekstraktu z rozmarynu na jakość hamburgerów drobiowych. Rocz. Inst. Przem. Mięs. Tłusz., 2008, XLVI (3), 43-50.

[27] PN-A-82109:2010. Mięso i przetwory mięsne. Oznaczenie zawartości tłuszczu, białka i wody. Metoda spektrometrii transmisyjnej w bliskiej podczerwieni (NIT) z wykorzystaniem kalibracji na sztucznych sieciach neuronowych (ANN).

[28] Ramadan M.F.: Black cumin (Nigella sativa) oils. Essential oils in food preservation. Flavor and Safety, 2016, 269-275. 
[29] Rozporządzenie Komisji (UE) nr 1129/2011 z dnia 11 listopada 2011 r. zmieniające załącznik II do rozporządzenia Parlamentu Europejskiego i Rady (WE) nr 1333/2008 poprzez ustanowienie unijnego wykazu dodatków do żywności. Dz. U. L 295, ss. 1-177, z 12.11.2011.

[30] Salem M.L.: Immunomodulatory and therapeutic properties of the Nigela satica L. seed. Int. Immunopharmacol., 2005, 5 (13-14), 1749-1770.

[31] Savadkoohi S., Hoogenkamp H., Shamsi K., Farahnaky A.: Color, sensory and textural attribites of beef frankfurter, beef ham and meat-free sausage containing tomato pomace. Meat Sci., 2014, 97, 410-418.

[32] Shahidi F.: The 2-tiobarbituric acid (TBA) methodology for the evaluation of warmed-over flavor and oxidative rancidity in meat products. $36^{\text {th }}$ Int. Congresses of Meat Science and Technology (ICoMST), Havana, Cuba, 1990, pp. 1008-1014.

[33] Turp G.Y.: Effects of four different cooking methods on some quality characteristics of low fat Inegol meatball enriched with flaxseed flour. Meat Sci., 2016, 121, 40-46.

[34] Van Hecke T., Ho P.L., Goethlas S., De Smet S.: The potential of herbs and spices to reduce lipid oxidation during heating and gastrointestinal digestion of a beef product. Food Res. Int., 2017, 102, 785-792.

[35] Wereńska M.: Naturalne antyutleniacze stosowane do mięsa. Nauki Inż. Technol., 2013, 1 (8), 79 90.

\title{
EFFECT OF BLACK CUMIN (NIGELLA SATIVA) ADDITIVE ON SELECTED PROPERTIES OF POULTRY MEATBALLS
}

\author{
S u m m a ry
}

The objective of the research study was to determine the effect of black cumin (Nigella sativa) additive on the selected quality parameters of poultry meatballs during two weeks of cold storage. Three variants of meatballs were produced, which differed in terms of the amount of black cumin added ( $\mathrm{K}-$ control variant without the black cumin additive, C- 0.2 - with $0.2 \%$ of black cumin added, C- 0.3 - with $0.3 \%$ of black cumin added). The following was determined in the finished products: chemical composition, volume of drip oozed during storage and cooking yield. Also there were measured: colour parameters in the CIE $\mathrm{L} * \mathrm{a} * \mathrm{~b} *$ scale, TBARS value, water activity and cutting force. An organoleptic evaluation of meatballs was also carried out; this evaluation covered the following parameters: colour, smell, taste, hardness and general desirability. The tests were carried out $24 \mathrm{~h}$ after production and after 1 and 2 weeks of their cold storage. The use of black cumin additive significantly slowed down fat oxidation processes occurring in vacuum packed poultry meatballs during two weeks of cold storage. $24 \mathrm{~h}$ after production, the mean TBARS values in roasted meatballs were $0.50 \div 0.62 \mathrm{mg} \mathrm{AM} / \mathrm{kg}$ of product. One week after storage there was a significant acceleration in lipid oxidation processes in all the variants of the meatballs produced, while the meatball variants with the black cumin added were characterized by lower values of the TBARS index. The black cumin added caused the colour of the products to become darker (lower values of the $\mathrm{L} *$ and $\mathrm{b} *$ colour parameters) and the cutting force to increase compared to the control product. According to the evaluators, the meatballs with $0.3 \%$ of black cumin added were characterized by the highest desirability. The results of the organoleptic evaluation indicate that the black cumin additive can be used in the production of products in the convenience food group and those products would be attractive to consumers.

Key words: black cumin, poultry meat, meatballs, quality, lipid oxidation 